\title{
Analysis of the Objectives and Classification of Punishments in Islām
}

\author{
Dr. Najmul Hasān \\ Assistant Professor, Department of Islamic Studies University of \\ Malākand, Pākistān \\ Aziz Ahmäd \\ Civil Judge District Swat, KPK, Pākistān
}

\begin{abstract}
:
Punishments of different categories are recognized by Isläm in the holy Qur'ān and Sunn'āh. These include punishments of Hadd, Punishments of Ta'zir and punishment of Siyäsä'h. The objectives of this punishment are different; some are for the welfare, reformation and protection of state and society while others are for the benefits of man. Sometime one particular sort of punishment is fixed and cannot be changed, no matter whatsoever the circumstances are, because these are determined by Allah as known by the name Hudüd i.e the God made punishments and cannot be altered by men. The other kind of punishment is Ta'zir, which is always at the discretion of the Judge and can be changed from time to time. Siyāsä'h is the third category of punishment which is in the interest of the state and is usually fixed by the state. In this article, an analysis of different categories of punishment as recognized by Isläm, shall be discussed in detail in the light of Sharia'h.
\end{abstract}

Key words: Isläm, Punishments, Objectives, Classifications, Hadd

\section{Introduction}

Isläm is a complete code of life. It's commandments cover every aspect of life. Rights of all types have been fixed which are fulfilling the basic needs of individuals. One of the basic needs of human being is security and peace. One cannot live happily without them. In order to secure peace and harmony, it must be ensured that no one commits any crime against humanity. For prevention of crime certain measures are required to be taken to protect the society, otherwise society will be at the mercy of the criminals.

Punishment plays a vital role in administering justice and they are basically meant to protect the society and promote peace. Laws are considered as a backbone in maintaining peace, settling disputes, quarrels 
and conflicts, which threaten the very existence of society and more than that, laws and punishments insure general security.

Islam provided all the required laws and rules for this purpose to secure the legitimate rights of all the people and punish the wrong doer. The rights in Islam are of two types i.e. rights of individual and rights of God. God has fixed intense punishments for violating His rights which actually protect the rights of general public. Hadd, Ta'zìr and Siyāsä'h are the three major types of punishments provided by Sharia'h.

F. H. Bradley, is of the view that punishment shall only be inflicted in extreme necessity, besides that, infliction of punishments will lead to injustice. ${ }^{1}$

Punishment means infliction of suffering on wrongdoers ${ }^{2}$ or the infliction or imposition of a penalty as retribution for an offense. ${ }^{3}$ A system of law exists in every civilized society and that's why punishing the wrong doer is a recognized norm in every society. Punishment is a form of compensation for offence. A person who transgresses law, incurs debt, justice requires compelling the wrong doer to pay the debt, which is the first objective of punishment to gratify law. ${ }^{4}$ A simple justification for punishment is that man is responsible for his action and deeds. According to Kant, punishment is retributive morally. ${ }^{5}$

\section{Concept in Isläm}

The main objective of punishment as described in the Qur'an is maintenance of peace in society. ${ }^{6}$ Punishment plays a vital role in the concept of justice. The main objective of sending messenger was maintenance of justice among the masses. In Isläm crimes are deemed to be committed against the whole society. ${ }^{7}$ The philosophy of Islam regarding the increase of crime or misconduct is embedded in prevention. ${ }^{8}$ The punishment mechanism in Isläm has been provided by divine authority, part of which is severe penalty. This severity operates as a deterrent factor against committing crime.

\section{Classification of Punishments in Isläm}

The concept of punishment in Isläm is entirely different from the concepts presented by human beings on their own. Criminal law is discussed in three separate chapters in classical textbooks of Fiqh, and not observed as a single unified branch of law. ${ }^{9}$ Crimes, for which punishment is already prescribed, are those acts which are considered as violation of right of Allah and the inflictions of such punishment are due to excess beyond the limits of Allah. ${ }^{10}$ If the legal right involved is of general nature they are termed as "Right of God" punishments meaning that the welfare of the society is measured on priority basis ${ }^{11}$. 
Such kinds of punishments are different due to certain distinguished characteristics mentioned below:

i. Qur'ānic punishments are fixed and it cannot be modified.

ii. Qur'ānic punishments cannot be waived by the $Q \bar{a} z \bar{\imath}$ or other law enforcing agency, but it shall be awarded in all circumstances where the required formalities of evidence etc are fulfilled.

iii. These are dealt as violation of right of Allah, therefore, great logic in maintenance of society is attached with them.

Basically there are three Classes of punishment in Islämic criminal law:

(1) Punishment of Hadd;

Crimes are specifically mentioned in the Holy Qur'än along with their punishments. Commission of such crimes is a sin against God and its punishments cannot be lessened by man's mercy, as God fixes them. Punishment of such crimes comprises limb imputation and death by stoning or beheading.

There are certain crimes for which punishments are prescribed, these crimes are considered as violation of rights of Allah and for them, punishments are fixed:
1. Sarqā
2. Harābā
3. Adultry
4. $Q a z ' f$
5. Shürb
6. Rebelling against the ruler
7. Apostasy (according to some schools of jurisprudence).

(2) Punishment of Qisās and Compensation

For private injury i.e murder and hurt, punishments are prescribed in the forms mentioned below:

1. Qisās

2. Diyä'h (blood money).

Qisās and Hudūd are illustrated in the Fiqh books with great precision.They have certain qualities, which distinguish them from other kind of laws, i.e

1. it must have been committed by adult person.

2. it must have been committed by a person of sound mind.

3. Formalities of evidence prescribed shall be mandatorily fulfilled.

4. Benefits of doubt shall go to the accused.. ${ }^{12}$

In Qisās the concept of deterrence plays an important role, though it 
is based on retribution. In this type ofcrimes the family of the victim can choose either retributive punishment or accept Diya 'h or blood money. In retribution there is infliction of the same sort on the body of the accused. Retribution is actually the application of general rule of "tit for tat" i.e. cutting off the same limb, which the criminal has done to the victim or if the victim is injured, the culprit will be injured without killing him, ${ }^{13}$ or to take Diya 'h (blood money), a fixed monetary compensation.

The perpetrator needs to be punished simply because he has committed crime.

In 2:178 of the Holy Qur'ān, Allah says: "Qisās is fixed for murder" And in 5:45 of the Qur'än; Allah says: "There is an revenge for inflicting a wound" (Qur'ān 5:45)

\section{Important Rules regarding Retribution}

However there are certain important rules concerning retribution:

Retribution can only take place if the killing or injuring/ wounding is deliberate, otherwise retribution will be unlawful. .

In Qisās the victim and his family is given choice to decide whether to punish the offender or not. In such offences, punishments are awarded as violation of private life and hence Isläm has permited the victim to pardon the criminal.

Allah says in 5:45

"If Qisās is waived then expiation shall be given."

Pardon can be either of the Diy $\bar{a}$ 'h or as a whole, without demanding any worldly compensation.

(3) Punishment of Ta'zīr and Siyāsä'h

Punishments which are at the discretion of the court when the offence is related to private injury is called Ta'zir.

$T a ' z i r$ is comprehensive category under which authorities are given wide-range of powers. Such crimes are not coming in the definitions of Hudüd. ${ }^{14}$ The authorities can punish under this category all crimes not described in Hudüd. These are flexible in nature and completely depend upon the discretion of the $Q \bar{a} z \bar{\imath} \bar{s}$ in accordance to his understanding of right right and justice as when the Holy prophet (S.W.A) sent Maāz to Yaman, he advised him to judge in accordance with the book of Allah and if he did not find anything in it then upon the Sunn'äh of the Holy prophet (S.W.A) and he did not find anything in it then advised to use his own opinion $^{15}$.

In Sharia'h, there are different categories of offences for which punishment may be inflicted according to discretion of the judges.

1. Offences not punishable under Hadd.

2. offences punishable under Hadd but fall short the limit like 
preliminary to theft.

3. Offences not punishable under Hadd due to mistake of law or facts. The other crime is Siyāsä'h. The Siyās $\bar{a}$ 'h is an offence against the Islamic state and the punishment of which shall be prescribed by the state. Objective of Punishment in Isläm

Islämic law punishments are fixed due to the following reasons.

i. Protection of society

ii. Deterrence of others

iii. Reformation

iv. Compensation

v. Expiation

vi. Retribution

vii. Restitution

Islamic criminal law has enunciated certain laws and rules to safeguard these necessities and principles, such as; the law of retribution is prescribed by Sharia'h to preserve life, punishment for apostasy is prescribed for the preservation of religion, to preserve reason, punishment for drinking is prescribed, punishment for fornication is prescribed to preserve lineage, to preserve wealth, punishment for theft is prescribed and to protect all of them, punishment for highway robber is prescribed. ${ }^{16}$

Severity is one of the main characteristics of Islamic criminal punishment. It is to discourage and limit the occurrence of crime. Due to this severity, most of the people will abstain from committing crime. In Islam the principle in presence of doubt is that these punishments are waived and the benefit of doubt is given to the accused. Another characteristic of these punishments is difficulty in establishing of guilt due to which the opportunity of carrying out these punishments is reduced and hence accused is protected from punishment on the ground of any speculation. These two characteristics help effectively in discouraging crime and protecting society as well as safeguarding the rights of the accused. Hence the rights of individual as well as rights of the society are secured.

There are many objectives of Islamic criminal law. Some of which are;

\section{1 .Protection of Society}

Society will be in great danger if crime is not curbed or countered with serious punishments. By fixing grave punishments Isläm is protecting society and people from the danger of crimes. As a result the society becomes stable, security prevail and thus life becomes more secure and peaceful.

\section{Deterrence of others}


By knowing the negative consequences of committing a wrong, a person will not dare to commit any crime or at least will think a thousand times before committing any. Thus the object of pre-determined laws is to educate all the people in general about the consequences of any wrong committed by anyone. And if a person commits any crime or violates any law, they will be punished accordingly and thus the criminal who has already been made subject to punishment will not recommit. And punishing wrongdoer serves as a deterrent factor for the society and will keep them away from commission of any crime. The principle of publicly announcing the carrying out of punishment is established by Isläm to realize a general effect from the punishment.

God says in Sürā'h Al-Nür:

"A group of the believers should witness the punishment."

\section{Reformation}

This is another object of Islamic penal system. Reformation of the criminal is another purpose sought by Isläm. Repentance is mentioned at various places in Qur'än in association with crime. Thus the door of repentance is always open for criminal provided that he aborts crime and starts behaving properly." 17

Thus repentance is an opportunity given to culprit for leaving the crimes and become a good person. This objective is often seen in discretionary punishments where the judge has to take into account the circumstances of the criminal and his betterment.

\section{Compensation}

The compensation for the crime is punishment. When the security of the society is in danger, it is undesirable that the criminal threat is taken lightly by any means. As long as the criminal chooses the evil path instead of the righteousness, then as per Islamic objective of penal law the criminal should receive his recompense. The safety and the security of the individuals and members of the society is their right to stand for. The Holy Qur'ān also emphasized on this objective when stating a number of punishments and penalties. God says in 5:38 of the Holy Qur'ann:

"The thieves, male and female, cut off their hands as a recompense for what they have earned."

\section{Expiation}

Expiation is fixed in Isläm as punishment, it has two main objectives first it is considered as punishment and secondly it is a type of ibādā'h as well. In which a person who has violated some rules is bound to fast, feed the poor or free a slave.

\section{Restitution}

In this kind of punishment there is compensation for loss suffered by 
one party by the illegal act of the other party, and the aggrieved party is paid back for their loss.

\section{Retribution}

It is a judicial revenge which is recognized by Isläm in order to satisfy the victim by inflicting the same injury on the body of the offender giving as inflicted by him.

\section{Explanation}

When the first Islamic state was established in Madinah by the Prophet (saw), the judicial and panel systems were implemented all inclusively. $\mathrm{He}$ (SAW) was also the first person who established the first Islamic state. At that time judiciary and executive were not separated as the same person was used to act as a judge as well as a ruler. Later on it was separated from executive at the time of Hazrat Ümar $(R A)$

\section{Conclusion}

From the above discussion it is clear that the penal system in Isläm is divided into three categories with fixed punishments for two types and the third is discretion and responsibility was on the state to fix the punishment. The objectives of punishment in Isläm are many including reformation of the criminals, deterring others and compensating the victims for their loss as well as ensuring rights and security of the people. However Isläm has also given the opportunity of reformation to the criminal by providing the principle of repentance.

Basically the punishments of Hudüd are fixed and it is inflicted on the wrongdoer for violating the rights of Allāh. The second one is Punishment of Ta'zir which are at the discretion of the judge and the third one is Siyāsā' $h$ which is to be fixed by the state and it is inflicted in case of violation of right of the state.

Its objectives are logical and meant to ensure peace in society, for compensate the aggrieved and criminal and establish justice among the human beings.

\section{Bibliography}

1. Introduction and the Islamic approach to combating crime. By The Editorial Team of Dr. Abdurrahman al-Muala Published on 08 March 2006 - Last modified on 16 Oct 2011

2. The philosophy of punishments in Islām,speech bydr. Iftikhar ahmad ayaz, o.b.e. jalsa salana uk 26th july 2009

3. TheEncyclopedia of Philosophy, (1967).V.7,New York: The Macmillan Company and The Free Press) 
4. Rudolph Peter (March 2006).Crime and Punishment in Islamic Law: Theory and Practice from the Sixteenth to the Twenty-first Century. Cambridge University publishing.

5. Shagufta Baigum (2007). Punishment as a social and moral agency.V. 27

6. http://bookzz.org/s/?q=themes+in+islamic +law\&t=0

7. http://www.cjimagazine.com/archives/cjia851.html?id=557

8. http://www.questionsonislam.com/print/9948

9. http://www.questionsonislam.com/printmail/9948

10. http://www.islamawareness.net/ Sharia'h/sh_fatwa005.html

11. http://www.islamreligion.com/articles/249/

12. http://www.islamic-study.org/islamic_penal_law.htm

13. http://islamicthinkers.com/welcome/?p=319

14. http://www.irfi.org/articles/articles_151_200/crime_and_punishme nt islam.htm

15. http://www.oxforddictionaries.com/definition/english/punishment

16. http://www.pakistan.web.pk/threads/punishments-in-islam.5460/

17. http:// Qur'ān.com/2/179

\section{Notes \& References}

1. Encyclopedia of Philosophy. 1967. V. 7

2. Shagufta Baigum (2007). Punishment as a social and moral agency. V. 27, P. 84,available at http://pu.edu.pk/images/journal/

3. http://www.oxforddictionaries.com/definition/english/punishment

4. Encyclopedia of Philosophy, (1967). V. 7

5. ibid P. 32

6. ibid. P. 83

7. http://www.islamawareness.net/ Sharia'h /sh_fatwa005.html

8. http://www.islamic-study.org/islamic_penal_law.htm

9. Rudolph Peter (March 2006). Available at http://bookzz.org/s/?q= themes+ in+islamic + law $\& \mathrm{t}=0$

10. http://www.pakistan.web.pk/threads/punishments-in-islam.5460/

11. ibid

12. Rudolph Peter (March 2006). http://bookzz.org/s/?q=themes+in+islamic+law\&t=0

13. ShaguftaBaigum (2007). Punishment as a social and moral agency. V. 27. P. 85, available at http://pu.edu.pk/images /journal/phill/ currentissue PDF /4\%20SHAGUFTA\%20Punishment.pdf

14. Rudolph Peter (March 2006).

Available at $\mathrm{http}: / /$ bookzz.org/s/?q=themes+in+islamic+law\&t=0 
15. Shagufta Baigum (2007). Punishment as a social and moral agency. V. 29. P. 85

17. http://www.pakistan.web.pk/threads/punishments-in-islam.5460/

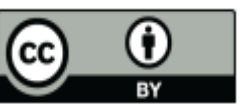

@ 2017 by the author, Licensee University of Chitral, Journal of Religious Studies. This article is an open access article distributed under the terms and conditions of the Creative Commons Attribution (CC BY) (http://creativecommons.org/licenses/by/4.0/). 